\title{
First record of the extinct sawfish Propristis schweinfurthi Dames, 1883 (Batoidea: Pristiformes: Pristidae) from the middle Eocene of Spain
}

\author{
Francesc Farrés · Harry Lee Fierstine
}

\author{
F. Farrés \\ Museu Geològic del Seminari de Barcelona/Geolab-Vic, \\ Diputació 231, 08007 Barcelona, Spain \\ e-mail: mariadolorsf@gmail.com \\ H. L. Fierstine \\ Biological Sciences Department, \\ California Polytechnic State University, \\ San Luis Obispo, CA 93407-0401, USA \\ e-mail: hfiersti@calpoly.edu \\ H. L. Fierstine \\ Section of Vertebrate Paleontology, \\ Natural History Museum of Los Angeles County, \\ Los Angeles, CA 90007, USA
}

\begin{abstract}
A partial rostrum of Propristis schweinfurthi Dames, 1883 was collected in the Bartonian strata of northeastern Spain. The specimen represents the second record of the species from Europe, and the second occurrence of a sawfish (Mesopristis osonensis Farrés, 2003) from the Vic-Manlleu Marls Formation. In spite of some evidence to the contrary, Propristis probably preferred ecological conditions similar to extant sawfishes, i.e., inhabiting nearshore tropical to subtropical seas with occasional excursions into freshwater.
\end{abstract}

Keywords Pristiformes - Sawfish - Propristis .

Bartonian · Spain

Zusammenfassung Ein fragmentarisches Rostrum des Sägefisches Propristis schweinfurthi Dames, 1883, wurde in bartonischen Ablagerungen Nordost-Spaniens gefunden. Das Exemplar ist der zweite Nachweis dieser Art für Europa und der zweite Fund eines Sägefisches in der VicManlleu Marls Formation. Trotz einiger gegensätzlicher Beweisfunde ist es wahrscheinlich, dass Propristis hauptsächlich küstennahe tropische and subtropische Meere und gelegentlich auch Süßwassergewässer besiedelte. Dies sind ökologische Anpassungen ähnlich denen, die lebende Sägefische bevorzugen.

Schlüsselwörter Pristiformes · Sägefisch · Propristis . Bartonian · Spanien

\section{Introduction}

The term sawfish refers to a batoid fish having an elongated flattened rostrum that is armored along each side with a single row of tooth-like structures [really spines, but referred to as teeth (Bigelow and Schroeder 1953, p. 16)]. Sawfishes belong to the family Pristidae, which includes two extant genera (Anoxypristis White \& Moy-Thomas, 1941; Pristis Linck, 1790) and three extinct genera (Mesopristis Farrés, 2003; Peyeria Weiler, 1935; Propristis Dames, 1883). Extant sawfishes usually inhabit nearshore marine, tropical and subtropical waters, but some species are regularly found in freshwater (Bigelow and Schroeder 1953, p. 19). Extinct sawfishes inhabited the Tethys Sea and the Atlantic Ocean from the early to late Eocene, and possibly from the Cretaceous to the Miocene (Cappetta 1987, pp. 158, 160).

The rostrum of the extinct sawfish Propristis schweinfurthi Dames, 1883 is unusual for a pristid. Whereas other pristids have elongated rostral teeth housed in deep alveoli along much of the length of the rostrum, the rostrum of Propristis bears flat, short teeth that are set in shallow alveoli only on the distal half or less of the rostrum (Fraas 1907, p. 3; Cappetta 1987, p. 158). Remains of Propristis, primarily isolated rostral teeth, have been found in Eocene deposits of North and West Africa, North America, and 
England (Cappetta 1987, p. 158). In the following report, we describe a partial rostrum of $P$. schweinfurthi that was collected from Bartonian strata of northeastern Spain. This specimen represents the second record of the species from Europe and the second occurrence of a sawfish [Mesopristis osonensis Farrés, $2003=$ Anoxypristis osonensis (Farrés 2003) according to Cappetta 2006, pp. 169, 277] from the Vic-Manlleu Marls Formation.

Institutional abbreviations: $G L V / M G S B$ Geolab Vic, Museu Geològic del Seminari de Barcelona, Spain;, SMNS Staatliches Museum für Naturkunde, Stuttgart, Germany.

Anatomical abbreviations: $c c e$ external calcified cartilage layer, $c c i-1$ outermost calcified cartilage layer, $c c i-2$ innermost calcified cartilage layer, $C P$ central platform, $C S$ central space, $L G$ lateral groove, $L L$ lateral lobe, $N C L$ lateral nerve canal, $N C M$ medial nerve canal.

Geological setting: Because the Propristis specimen was collected in the Vic-Manlleu Marls Formation, northeastern Spain, we confine our discussion to the geological setting of the Ebro Foreland Basin (Figs. 1, 2). According to Pisera and Busquets (2002, p. 322), a large westward-opening marine gulf covered the continental shelf south of the Pyrenees during the Bartonian. Rivers carrying sediments into the gulf from the Pyrenees and Catalan Coastal Ranges deposited sands and conglomerates into nearby areas of the Ebro Basin, and thick marl sequences formed in more distant areas of the basin.

The Vic-Manlleu Marls Formation (middle Eocene, Bartonian) has a total thickness of over $200 \mathrm{~m}$ and is composed of four members (Almela 1946; Reguant 1967): (1) The Vic Member is located at the base of the formation and consists of gray marls with remains of poorly preserved carbonized plants and occasionally sponges (Farrés et al. 2005, p. 76). (2) The La Giuxa Marl Member overlies the Vic Member and is composed of gray marls with abundant sponge remains; its contact with the Gurb Marl Member is difficult to distinguish lithologically, hence the dashed line in Fig. 2. (3) The Gurb Marl Member is composed of marls and carbonaceous siliciclastics that contain foraminifers, sponges, bryozoans, brachiopods, annelids, molluscs, echinoderms, and crustaceans. (4) The Vespella Marl Member consists of marls and lutites with some interbedded well-cemented sandstones. Fossils are sparse in the Vespella Marl Member, except in its lower part, where there is an interesting fauna containing mollusks, sawshark (M. osonensis Farrés 2003), several lamniform sharks including Carcharocles Jordan \& Hannibal 1923 (= Otodus Agassiz, 1843: 266 according to Cappetta 2006, p. 343), and the putative perciform fish, Cylindracanthus rectus (Agassiz, 1843) (Farrés 2003,
Fig. 1 Collection site of GLV/ MGSB 74.000, Propristis schweinfurthi Dames, 1883 showing the distribution of stratigraphic units and the location of the Vic Area (District), northeastern Spain (Catalonia) (adapted from Serra-Kiel et al. 2003)

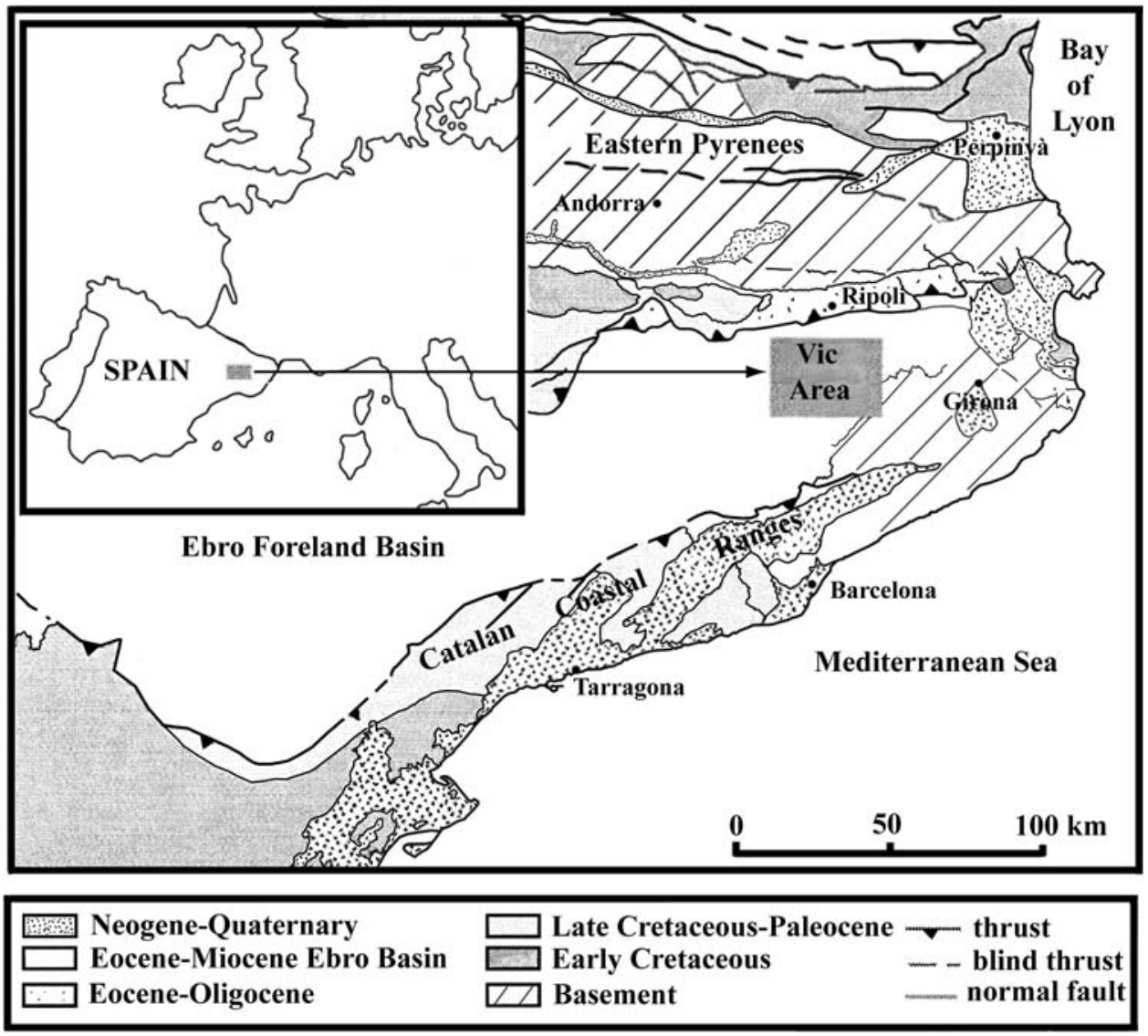


Fig. 2 Stratigraphic column of Bartonian (middle Eocene) units in the Vic Area with chronostratigraphic stages (Chron) and biozones (SBZ) based on shallow-water benthic foraminifera (Serra-Kiel et al. 1998, 2003). Fm Formation, $\mathrm{Mbr}$ member, Env paleoenvironments, $P$ stratigraphic level of the Propristis specimen

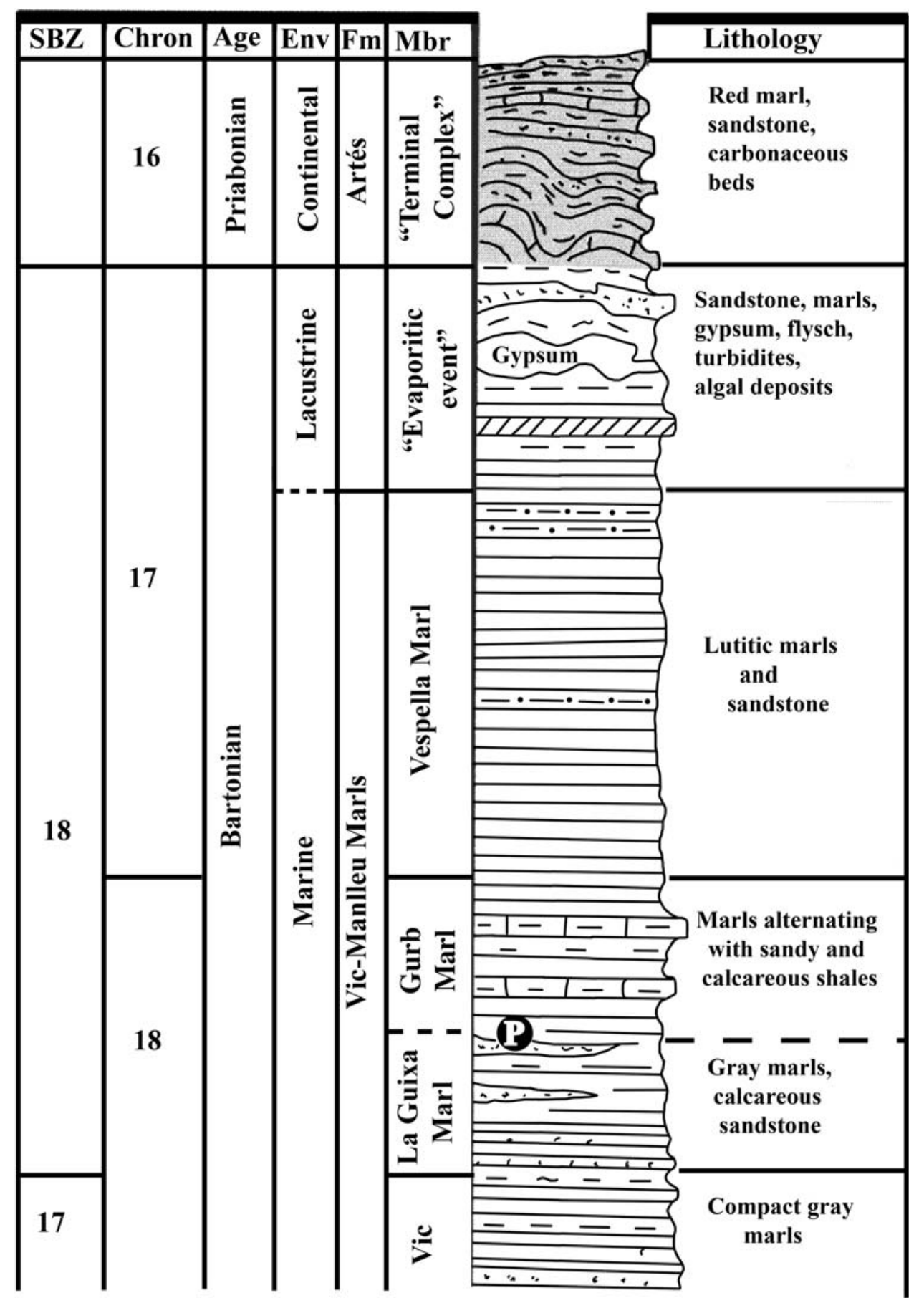

p. 98; Farrés and Altimiras 2007, pp. 37, 38). The Vespella Marl Member grades upward into a lacustrine series ("evaporitic event" in Fig. 2), with an algal layer in the lowermost stratum followed by layers of turbidites, evaporites (gypsum), and arenaceous flysch. The flysch is composed of siliciclastic facies of marl and shallow turbiditic sandstone that are typical of a barren river basin with restricted contact with marine waters (Farrés and Staid-Staadt 1964). The Bartonian strata are capped by the "terminal complex" of the Artés Formation, a continental deposit of Priabonian age that is composed of sandstones and red marls (Serra-Kiel et al. 2003, p. 220).

\section{Systematic paleontology}

Class Chondrichthyes Huxley, 1880

Subdivision Batoidea sensu Nelson, 2006

Order Pristiformes sensu McEachran \& Aschiliman, 2004 
Family Pristidae Bonaparte, 1838

Genus Propristis Dames, 1883

Type species: Propristis schweinfurthi Dames, 1883

Diagnosis: The following is excerpted mainly from Cappetta (1987, p. 158), but also in part from Stromer (1905, p. 55) and Fraas (1907, pp. 2-5): Rostrum is very long and narrow, and its ventral and dorsal surfaces convex proximally, but are flat distally. Lateral margins of the rostrum are nearly parallel throughout their length, whereas the dorsoventral thickness is thin. Alveoli are shallow notches and only on the lateral margins of the distal $45 \%$ of the rostrum. In cross-section of the rostrum, there is a central space representing the prolongation of the precerebral cavity and a pair of lateral canals, one large and one small in diameter, on each side of the central space. Rostral teeth (up to $3 \mathrm{~cm}$ in length) are devoid of enamel covering, flat (thin dorsoventrally) and more or less as wide (anteroposterior length) as long (apicobasal length). The base of each tooth is convex, and its apical angle is obtuse or close to $90^{\circ}$. Both the anterior and posterior borders of each tooth form a sharp cutting edge, and each tooth overlaps the one anterior and posterior to it. The basal part of the dorsal and ventral surfaces of each tooth bears shallow, vertical grooves (striations).
Propristis schweinfurthi Dames, 1883

(Figs. 3, 4)

Type specimens: two rostral fragments and three teeth collected by Prof. G. Schweinfurth in the Birket Qarun Formation, early late Eocene (early Priabonian), Island of Lake Birket Qarun, Fayum Province, Egypt.

Material examined: GLV/MGSB 74.600, a partial rostrum in two separate pieces, a long posterior (proximal) segment and a short anterior (distal) segment.

Locality and age: Múnter, Ebro Foreland Basin, Catalonia, northeastern Spain, contact between La Guixa Marl and Gurb Marl members, Vic-Manlleu Marls Formation (middle Eocene, Bartonian).

Description and comparison with other pristids: The preserved rostrum is composed of two separate, nonarticulating segments, a long proximal (posterior) section and a shorter, distal (anterior) section (Fig. 3). We estimate that at least $500 \mathrm{~mm}$ of the rostrum is missing between the two segments. Both segments have a small amount of matrix attached to their ventral surfaces.

The proximal segment is $600 \mathrm{~mm}$ long and its width gradually tapers from $88 \mathrm{~mm}$ proximally to $64 \mathrm{~mm}$ distally (Fig. 3a). The dorsal and ventral surfaces are slightly convex. The lateral margins are smooth and lack alveoli.

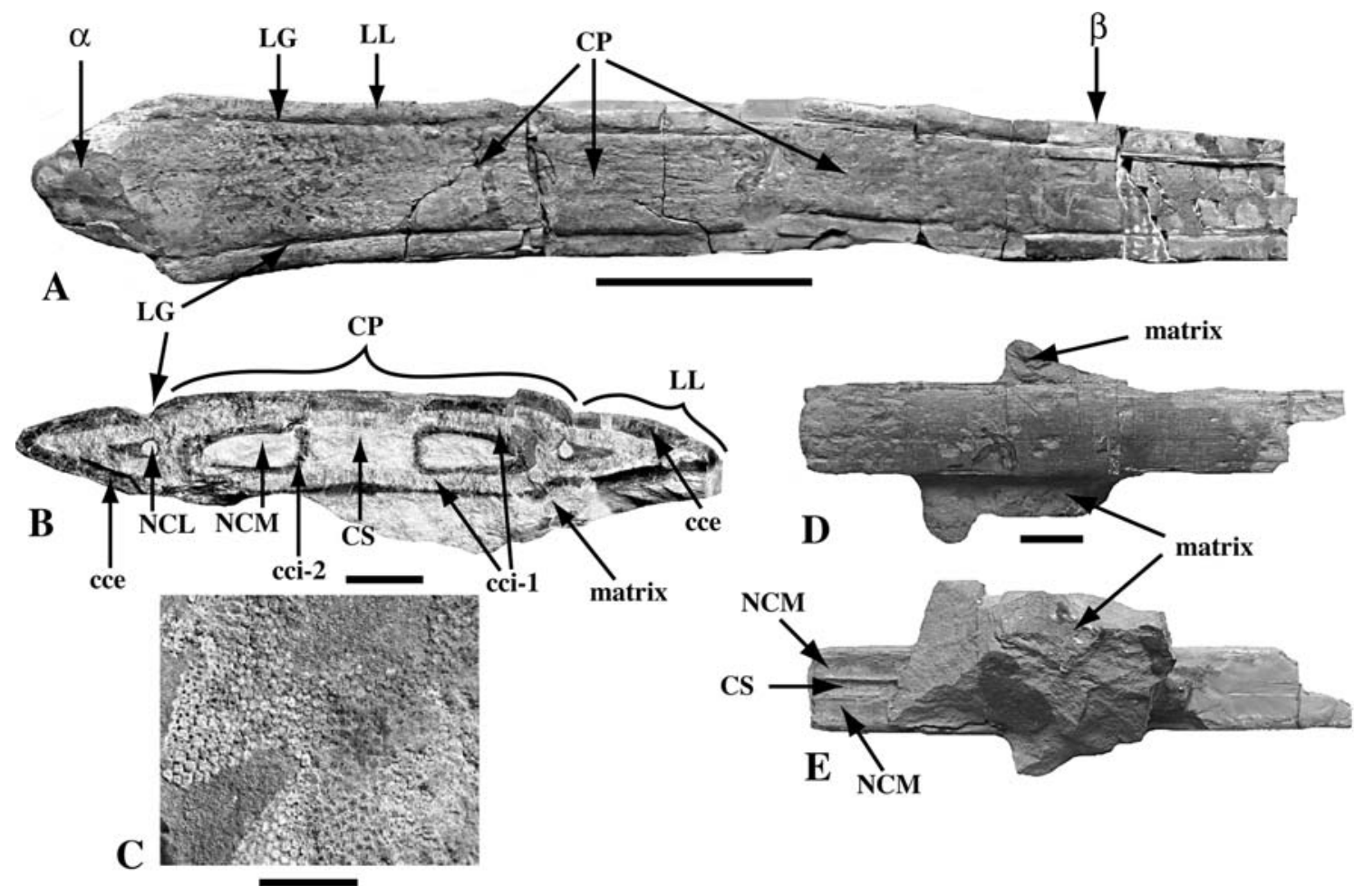

Fig. 3a-e Partial rostrum of Propristis schweinfurthi Dames, 1883, specimen GLV/MGSB 74.000, Vic-Manlleu Marls Formation, middle Eocene, Osona (Vic), Barcelona Province, Spain. a Posterior (proximal) segment, dorsal view. b Cross-section at position beta $(\beta)$ in a. c Prismatic columns of cci- 1 marked by alpha $(\alpha)$ in a. d Anterior (distal) segment, dorsal view. e Anterior (distal) segment, ventral view. Scale bars equal $10 \mathrm{~cm}(\mathbf{a}), 2 \mathrm{~cm}(\mathbf{d}, \mathbf{e}), 1 \mathrm{~cm}(\mathbf{b}, \mathbf{c})$. Abbreviations defined in text 


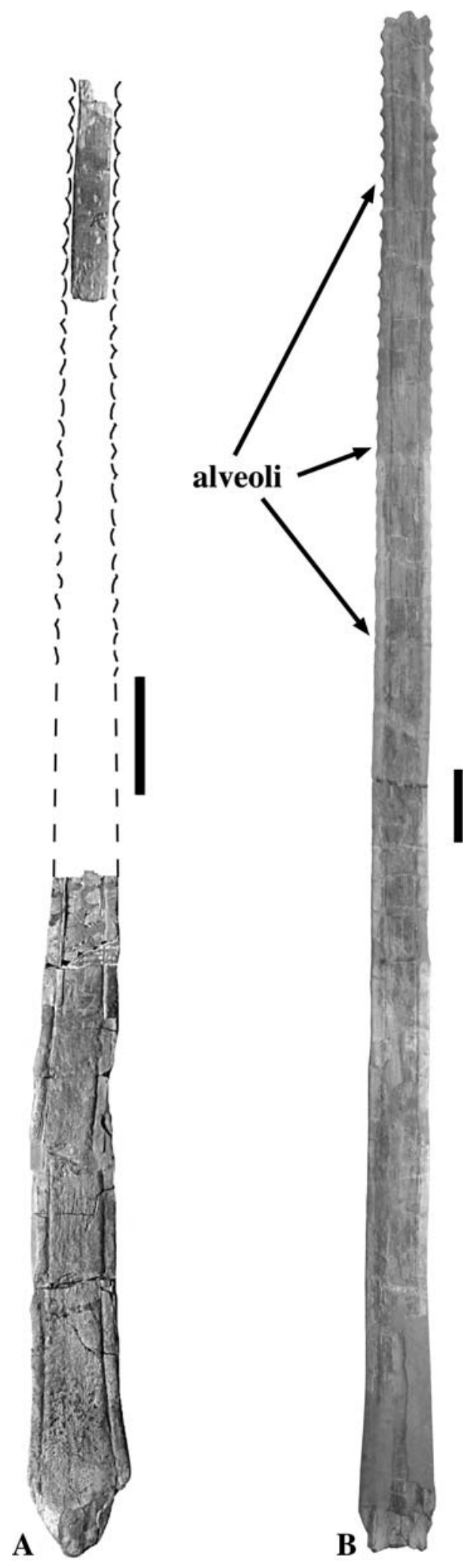

Fig. 4a, b Rostrum of Propristis schweinfurthi Dames, 1883. a Reconstruction of specimen GLV/MGSB 74.000, Vic-Manlleu Marls Formation, middle Eocene, Osona (Vic), Barcelona Province, Spain. b Specimen SMNS 11847, Birket Qarun Formation, late Eocene, Fayum Province, Egypt. Scale bars equal $10 \mathrm{~cm}(\mathbf{a}, \mathbf{b})$
A pair of shallow grooves (LG) extends along the length of the dorsal and ventral surfaces of the segment, dividing the surfaces into a broad, central platform (CP) and a pair of much narrower lateral lobes (LL). The CP varies in width from $65 \mathrm{~mm}$ proximally to $37 \mathrm{~mm}$ distally. The width of LL remains constant at $12 \mathrm{~mm}$. Using the terminology of Casier (1949, pp. 51-52), the proximal segment of the rostrum is composed of three calcified cartilage layers (Fig. 3b), the external layer (cce) and two internal layers (cci-1 and cci-2). In addition, the cross-section shows two pairs of nerve canals, a medial pair (NCM) and a lateral pair (NCL). The cce has a fibrous (woody) texture and forms the exterior of the rostrum. The cce- 2 forms the walls of each nerve canal, and the cce- 1 fills the area between cce and cce- 2 . The cce- 1 is composed of prismatic columns that are oriented perpendicular to the surface of the rostrum (Fig. 3c). The CS is located at the center of the cross-section and is more or less rectangular in shape. Matrix fills the nerve canals and CS. Each NCM, located immediately lateral to the CS, has an ovate outline with a vertical inner margin. The NCM is larger in diameter (varying from 16.3 proximally to $10 \mathrm{~mm}$ distally) than the two NCL, which have a circular outline (varying from $3.0 \mathrm{~mm}$ proximally to $1.8 \mathrm{~mm}$ distally).

The anterior (distal) rostral segment is $200 \mathrm{~mm}$ long and $30 \mathrm{~mm}$ wide along its entire length. It is incomplete and composed only of the dorsal half of the CP (Fig. 3d, e). The LL and alveoli are not preserved. Remnants of the CS and both NCM are visible (Fig. 3e) in ventral view.

Although there is a large part of the rostrum missing between the anterior and distal segments, we have attempted to reconstruct the rostrum into a single unit based primarily on the width of the central platform (Fig. 4a). We estimate its original length at slightly greater than $1 \mathrm{~m}$ by using the method of extending the lateral margins of the posterior section distally until they converge and then inserting the anterior section within the extended margins to a position that would leave room for the LL.

\section{Discussion and conclusions}

Propristis schweinfurthi is characterized by four features (Fraas 1907: pl. 1, fig. 1, 2; Cappetta 1987, p. 158), all of which are related to the rostral teeth, including: (1) broad flat, double-edged teeth, all of similar size; (2) shallow, broad alveoli; (3) teeth located only on the distal $45 \%$ (see discussion below) of the rostrum; (4) each tooth partially overlapping the one anterior and posterior to it. Other extinct and extant pristids, such as Anoxypristis and Pristis, with the possible exception of $M$. osonensis, have elongated, pointed rostral teeth that are anchored to the rostrum. The rostral teeth of Mesopristis are elongated, rounded at 
their distal tip, but housed in moderately shallow alveoli. However, each alveolus of Mesopristis contains a projection that fits into a groove at the base of the tooth, forming a mortise-and-tenon joint, a morphology unlike any other pristid (Farrés 2003, p. 105). Fraas (1907, p. 3) concluded that alveoli were only present in the distal one-fourth of the rostrum, but after measuring a recent photograph of the specimen he studied (SMNS 11847), which is the longest $(2.07 \mathrm{~cm})$ and only complete specimen of $P$. schweinfurthi known (Fig. 4b), we calculated that the value is closer to $45 \%$. The alveoli are moderately deep distally and very shallow (incipient) proximally. We essentially agree with Cappetta (1987, p. 158) who reported alveoli only along the distal one-half of the rostrum.

In cross-section, Propristis, Anoxypristis (Stromer 1921: text-fig. 5; Cappetta 1987: text-fig. 137F; Kirkland and Aguillón-Martinez 2002: text-fig. 7B), and Mesopristis (Farrés 2003: pl. 2, figs. 3, 4) have similar morphologies. The CS is flanked on each side by the NCM and more lateral NCL. Casier (1949: 12, text-fig. 1, pls. 1, 2, 4) discussed and figured a similar arrangement for Pristis lathami Galeotti, 1837 and Pristis propinquidens Casier, 1949, except that the most lateral pair of canals (cvl of Casier 1949) are elongated in the interdental areas and surrounded by the outermost calcified cartilage layer (cci1), not the innermost calcified cartilage (cci-2) as seen in Anoxypristis, Mesopristis, and Propristis. Cicimurri (2007, p. 598) referred to the "lateral canals" of Pristis as lateral cavities (lc) noting that they are not homologous to the true NCL of Anoxypristis because they do not form a continuous lateral canal. Because the NCL of Anoxypristis, Mesopristis, and Propristis are morphologically similar, they presumably housed nerves associated with the Ampullae of Lorenzini [see Kirkland and Aguillón-Martinez (2002: 20, text-fig. 7b)].

Our identification of specimen GLV/MGSB 74.600 as $P$. schweinfurthi is based on circumstantial evidence because the rostral fragments lack teeth or alveoli. However, the rostral teeth of Pristis extend from the base of the rostrum to the distal tip (Bigelow and Schroeder 1953: text-figs. 2-6; Slaughter \& Springer 1968: text-fig. 3B) and along the distal three-fourths of the rostrum of Anoxypristis (Mould 1994). The proximal segment of the Vic specimen is long and complete enough that it should have had alveoli or rostral teeth visible if it belonged to either of these two genera. The alveoli of the Mesopristis holotype extend from the base of the rostrum to its distal tip, but the specimen is incomplete and the extent of alveoli along the length of a complete rostrum is unknown (Farrés 2003). Additionally, there are four longitudinal grooves on the dorsal surface of the rostrum of Mesopristis, whereas there are only two on the dorsal surface of a Propristis rostrum. Thus, we conclude that GLV/MGSB 74.600 is a rostrum of
$P$. schweinfurthi, and our reconstruction is illustrated in Fig. 4a.

Propristis schweinfurthi has been reported from the early Eocene of Virginia, U.S.A. (Kent 1999, p. 41); the middle Eocene of Nigeria (White 1926, p. 49), Togo (Cappetta 1987, p. 158), and England (Kemp et al. 1990, p. 10); the middle or late Eocene of Arkansas, U.S.A. (Westgate 2001, p. 284); the late Eocene of Egypt (Stromer 1905, p. 53; Fraas 1907; Case and Cappetta 1990, pp. 19-20, pl. 9 fig. 216, 220-222), Georgia, U.S.A. (Dunkle 1951, p. 346; Case 1981, p. 71), and Louisiana, U.S.A. (Manning and Standhardt 1986, p. 139; Breard and Stringer 1995, p. 82); the Eocene of Cabinda (Angola) (Dartevelle and Casier 1943, pp. 169-170, pl. 14 fig. 17, 18); and according to Case and Cappetta (1990, p. 20), most questionably from the Miocene of Cabinda (Angola) (Dartevelle and Casier 1943, p. 170). Thus, the Vic specimen is the first record of $P$. schweinfurthi from the European continent. The presence of Propristis in Spain should not be unexpected because the taxon is considered one of the marine vertebrates that inhabited the Tethys Sea during the Eocene (Manning 2003, p. 375). What is puzzling is the absence of Propristis in European Eocene marine deposits (e.g., Casier 1946, 1949; Leriche 1951; Blot 1980) other than the Hampshire Basin of England (Kemp et al. 1990, p. 10) and the Ebro River Basin of Spain. Propristis is associated with Pristis lathami in Eocene deposits of equivalent age in West Africa (White 1926, p. 50) and North America (Kent 1999, p. 40; Westgate 2001, p. 287) but not in the Belgian and Paris basins (Leriche 1906; Casier 1949).

Propristis schweinfurthi probably preferred ecological conditions similar to extant sawfishes, i.e., inhabiting nearshore tropical and subtropical waters with occasional excursions into freshwater (Bigelow and Schroeder 1953, pp. 11, 12). Most paleoecological interpretations of strata with remains of Propristis support this hypothesis. For example, Westgate (2001, pp. 277, 284) interpreted one site (Hardie Mine Local Fauna, Clinchfield Formation, Georgia, U.S.A.) as a diverse nearshore marine community and another site (Crow Creek Local Fauna, Jackson Group, Arkansas, U.S.A.) as a diverse estuarine vertebrate fauna. The Selsey Formation in England was deposited in a shallow, warm sea with estuarine horizons (Kemp et al. 1990, p. 2). Manning and Standhardt (1986, p. 136) described the Moodys Branch Formation at Montgomery Landing, Louisiana, U.S.A., as an inner shelf deposit (10-20 $\mathrm{m}$ in depth) while Breard and Stringer (1995, p. 82) characterized the Yazoo Clay at Copenhagen, Louisiana, as an inner shelf deepening upsection to a middle shelf. In contrast to the above paleoecological interpretations, the holotype was collected in the Birket Qarun Formation, a lithostratigraphic unit that represents an offshore (submerged) barrier 
complex on the continental shelf (Gingerich 1992, p. 63). Unfortunately, the paleoecology of the Vic specimen is difficult to assess because it was collected in a contact between two members of the Vic-Manlleu Marls Formation (Fig. 2), each having a different paleoecological interpretation. According to Pisera and Busquets (2002, p. 325), based on sponge remains, the La Guixa Marl Member exposed in the area around Múnter represented an aphotic distal shelf deposited in $200 \mathrm{~m}$ or more of water, and SerraKiel et al. (2003, p. 215) concluded that fossil bryozoa in the La Guixa Marl Member around Serratosa farm (1.5 km NE of the town of Sant Hipolit de Voltregà) indicated an aphotic part of the shelf. However, Pisera and Busquets (2002, p. 325) concluded that the Gurb Marl Member represents sediments that were deposited under shallow water, euphotic conditions. Thus, the presence of Propristis in the Vic-Manlleu Formation neither supports nor refutes the hypothesis that $P$. schweinfurthi probably preferred nearshore, tropical and subtropical waters.

Acknowledgments Our sincere gratitude to Dr. France de Lapparent de Broin, Muséum National d'Histoire Naturelle, Laboratoire de Paléontologie, Paris, for being the intermediary that led to our collaboration. Dr. X. Murelaga, Euskal Herriko Unibertsitatea, Departamento Estratigrafía y Paleontología, País Vasco, Spain; D. Cicimurri, Clemson University, South Carolina, USA; G. Stringer, University of Louisiana, Monroe, LA, USA; and three anonymous reviewers critiqued earlier drafts of the manuscript and provided important suggestions for improvement. We are also grateful for the assistance and support of J. Altimiras, R. Cano, M. D. Farrés, D. Marsal, and A. Fierstine. J. Kriwet, Staatliches Museum für Naturkunde, Stuttgart, Germany, kindly provided the photograph of SMNS 11847 shown in Fig. 4b and verified the position of the posterior most alveolus in the specimen. L. Tomanek, Cal Poly, San Luis Obispo, California, USA, provided the Zusammenfassung.

\section{References}

Agassiz, L. 1833-1843. Recherches sur les poissons fossiles. Neûchatel" Petitpierre.

Almela, A. 1946. Manlleu, Hoja no 294, 52 p. Madrid: Instituto Geológico y Minero de España.

Bigelow, H.B., and W.C. Schroeder. 1953. Part two. Sawfishes, guitarfishes, skates, and rays. In Fishes of the Western North Atlantic: 1-514, ed. J. Tee-van, 588 pp. New Haven: Sears Foundation for Marine Research, Memoir number 1.

Blot, J. 1980. La faune ichthyologique des gisements du monte Bolca (Province de Vérone, Italie). Catalogue systématique présentant l'état actuel des recherches concernant cette faune. Bulletin Muséum National d'Histoire Naturelle, Paris, Série 4, 2(1980, section C, No. 4): 339-396.

Bonaparte, C.L. 1838. Selachorum tabula analytica, 195-214. Bologna: Nuovi Annali della Scienza Naturali.

Breard, S.Q., and G.L. Stringer. 1995. Paleoenvironment of a diverse marine vertebrate fauna from the Yazoo Clay (Late Eocene) at Copenhagen, Caldwell Parish, Louisiana. Gulf Coast Association of Geological Societies Transactions 45: 77-85.
Cappetta, H. 1987. Chondrichthyes II: Mesozoic and Cenozoic Elasmobranchii. In Handbook of Palaeoichthyology, vol. 3B, ed. H.-P. Schultze, 193 pp. New York: Gustav Fischer Verlag.

Cappetta, H. 2006. Fossilium Catalogus I: Animalia, pars 142. Elasmobranchii Post-Triadici (Index specierum et generum), 472 pp. Leiden: Backhuys.

Case, G. 1981. Late Eocene selachians from south-central Georgia. Palaontographica Abteilung A 176: 52-79.

Case, G., and H. Cappetta. 1990. The Eocene selachian fauna from the Fayum Depression in Egypt. Palaeontographica Abteilung A, Paläozoologie-Stratigraphie 212(1-6): 1-30.

Casier, E. 1946. La faune ichthyologique de l'yprésien de la Belgique. Mémoires de Musée Royal d'Histoire Naturelle de Belgique 104: $1-267$.

Casier, E. 1949. Contributions a l'étude des poissons fossils de la Belgique. VIII. Les Pristidés éocènes. Bulletin Institut Royal des Sciences Naturelles de Belgique 25(10): 1-52.

Cicimurri, D.J. 2007. A partial rostrum of the sawfish Pristis lathami Galeotti, 1837, from the Eocene of South Carolina. Journal of Paleontology 81(3): 597-601.

Dames, W. 1883. Über eine tertiäre Wirbelthierfauna von der westlichen insel des Birket-el-Qurûn im Fajum (Aegypten). Sitzungsberichte-Bayerische Akademie der Wissenschaften Berlin 6: 129-153.

Dartevelle, E., and E. Casier. 1943. Les poissons fossiles du BasCongo et des régions voisines. Annals du Musée du Congo belge, Serie A, part I 2: 1-200.

Dunkle, D.H. 1951. New western hemisphere occurrences of fossil selachians. Journal of the Washington Academy of Science 41(11): 344-347.

Farrés, F. 2003. Mesopristis nov. gen. osonensis nov. sp., Nuevo género y especie de pez-sierra del Eoceno de Vic (Catalunya, N.E. de España). Batalleria 11(2002-03): 93-113.

Farrés, F., and J. Altimiras. 2007. El género Cylindracanthus en el Eoceno de Vic (Barcelona). Batalleria 13: 37-46.

Farrés, F., and J. Staid-Staadt. 1964. Las correlaciones faciales del Lediense y su fauna de moluscos en la comarca de Vich. Ausa, 42. Vic: Patronato de Estudios Ausonenses.

Farrés, F., J. Vicente, and J. Altimiras. 2005. Distribución estratigráfica de la flora eocénica en la comarca de Vic (Osona) Barcelona. Batalleria 12: 75-104.

Fraas, E. 1907. Säge von Propristis schweinfurthi Dames aus dem oberen Eocän von Ägypten. Neues Jahrbuch für Mineralogie und Paläontologie 1907(1): 1-6.

Galeotti, H. 1837. Mémoire sur la constitution géognostique de la Brabant. Mémoire de l'Academie des Sciences de la Belgique, 4, 12 (3): 1-193.

Gingerich, P. 1992. Marine mammals (Cetacea and Sirenia) from the Eocene of Gebel Mokattam and Fayum, Egypt: stratigraphy, age, and paleoenvironments. University of Michigan, Papers on Paleontology no. 30: 1-84.

Huxley, T. 1880. A manual of the anatomy of vertebrated animals, 431 pp. New York: D. Appleton.

Jordan, D.S., and H. Hannibal. 1923. Fossil sharks and rays of the Pacific slope of North America. Southern California Academy of Sciences, Bulletin 23: 27-63.

Kemp, D., L. Kemp, and D. Ward. 1990. An illustrated guide to the British Middle Eocene Vertebrates, 59 pp. London: Self published.

Kent, B.W. 1999. Part 3. Rays from the Fisher/Sullivan Site. In Early Eocene vertebrates and plants from the Fisher/Sullivan Site (Nanjemoy Formation) Stafford County, Virginia, eds. R.E. Weems and G.J. Grimsley, 39-51. Virginia Division of Mineral Resources, Publication 152. 
Kirkland, J.I., and M.C. Aguillón-Martinez. 2002. Schizorhiza: a unique sawfish paradigm from the Difunta Group, Coahuila, Mexico. Revista Mexicana de Ciencas Geológicas 19(1): 16-24.

Leriche, M. 1906. Contribution a l'etude des Poissons fossiles du Nord de la France et des régions voisines. Mémoires de la Sociéte Geológique du Nord 5: 1-430.

Leriche, M. 1951. Les Poissons tertiaires de la Belgique (Supplément). Mémoires du Musée Royal d'Histoire Naturelle de Belgique 118: 474-600.

Linck, H.F. 1790. Versuch einer Eintheilung der Fische nach den Zähnen. Magazin für das Neueste aus der Physik und Naturgeschichte 4: 28-38.

Manning, E.M. 2003. The Eocene/Oligocene transition in marine vertebrates of the Gulf Coastal Plain, Chapter 21. In From greenhouse to icehouse, the marine Eocene-Oligocene transition, ed. D.R. Prothero, L.C. Ivany, and E.A. Nesbitt, 366-385. New York: Columbia University Press.

Manning, E.M., and B.R. Standhardt. 1986. Late Eocene sharks and rays of Montgomery Landing, Louisiana. In Montgomery Landing site, Marine Eocene (Jackson) of Central Louisiana, eds. J.A. Schiebout and W. van den Bold, 133-161. Proceedings of a Symposium, Gulf Coast Association of Geological Societies, Baton Rouge, Louisiana, 238 pp.

McEachran, J.D., and N. Aschiliman. 2004. Phylogeny of Batoidea. In Biology of sharks and their relatives, ed. J.C. Carrier, J.A. Musick, and M.R. Heithaus, 79-113. Boca Raton, Florida: CRC Press.

Mould, B. 1994. Anoxypristis cuspidate. In FishBase World Wide Web electronic publication, eds. R. Froese and D. Pauly. www.fishbase.org, accessed 01/2008.

Nelson, J.S. 2006. Fishes of the world, 4th ed, 601 pp. New York: Wiley.

Pisera, A., and P. Busquets. 2002. Eocene siliceous sponges from the Ebro Basin (Catalonia, Spain). Geobios 35: 321-346.
Reguant, S. 1967. El Eoceno marino de Vic (Barcelona). Memorias del Instituto Geológico y Minero de España 68: 1-350.

Serra-Kiel, J., L. Hottinger, E. Caus, K. Drobne, C. Ferràndez, A. Jauhri, G. Less, R. Pavlovec, J. Pignatti, J. Samsó, H. Schaub, E. Sirel, A. Strougo, Y. Tambareau, J. Tosquella, and E. Zakrevskaya. 1998. Larger foraminiferal biostratigraphy of the Tethyan Paleocene and Eocene. Bulletin de la Société géologique de France 169(2): 281-299.

Serra-Kiel, J., A. Trave, E. Mató, E. Saula, C. Ferrández-Cañadell, P. Busquets, J. Tosquella, and J. Vergés. 2003. Marine and transitional Middle/Upper Eocene units of the Southeastern Pyrenean Foreland Basin (NE Spain). Geological Acta 1(2): 177-200.

Slaughter, B.H., and S. Springer. 1968. Replacement of rostral teeth in sawfishes and sawsharks. Copeia 1968(3): 499-506.

Stromer, E. 1905. Die Fischreste des mittleren und oberen Eocäns von Ägypten. I. A Myliobatiden und Pristiden. Beitrage zur Paläontologie und Geologie Österreich-Ungarns etc 18: 37-56.

Stromer, E. 1921. Der Bau, die Funktion und die Entstehung der Sägen der Sägehaie. Fortschritte Naturwissenschaften Forschung 2: 113-124.

Weiler, W. 1935. Ergebnisse der Forschungsreisen Prof. E. Stromers in den Wüsten Ägyptens. II. Wirbeltierreste der Baharîje-Stufe (unterstes Cenoman). 16. Neue Untersuchungen an den Fischresten. Abhandlungen der Bayerischen Akademie der Wissenschaftliche Abteilung (n.f.) 32: 1-57.

Westgate, J.W. 2001. Paleoecology and biostratigraphy of marginal marine Gulf Coast Eocene vertebrate localities. In Eocene biodiversity: unusual occurrences and rarely sampled habitats, ed. G.F. Gunnell, 263-297. New York: Kluwer Academic.

White, E.I. 1926. Eocene fishes from Nigeria. Bulletin of the Geological Survey of Nigeria 10: 7-87.

White, E.I., and J.A. Moy-Thomas. 1941. Notes on the nomenclature of fossil fishes. Pt. III. Annals and Magazine of Natural History 7(11): 395-400. 